\title{
KEMAMPUAN MAHASISWA PENDIDIKAN GEOGRAFI MELALUI PENUGASAN PEMBUATAN BLOG PADA MATA KULIAH TEKNOLOGI INFORMASI DAN KOMUNIKASI SEMESTER GASAL TAHUN AJARAN 2015/2016
}

\author{
Murjainah \\ Program Studi Pendidikan Geografi, Universitas PGRI Palembang, \\ (凹) murjainah@gmail.com / murjainah@univpgri-palembang.ac.id
}

\begin{abstract}
ABSTRAK
Penelitian ini bertujuan untuk mengetahui kemampuan mahasiswa Pendidikan Geografi melalui penugasan pembuatan Blog pada mata kuliah Teknologi Informasi dan Komunikasi (TIK). Metode yang digunakan dalam penelitian ini adalah kualitatif. Sampel yang digunakan dalam penelitian ini adalah purposive sampling, yaitu kelas $3 \mathrm{C}$ berjumlah 33 mahasiswa. Teknik pengumpulan data pada penelitian ini menggunakan tes dan dokumentasi. Analisis data dalam penelitian ini dilakukan secara deskriptif karena mendeskripsikan kemampuan mahasiswa pendidikan geografi dalam membuat Blog. Berdasarkan hasil penelitian menunjukkan bahwa secara keseluruhan kemampuan mahasiswa pendidikan Geografi termasuk kategori baik dengan persentase 83\%. Artinya, mahasiswa dapat membuat Blog dengan baik yakni dilihat dari kemampuannya membuat Blog dan mengumpulkan alamat URL Blog, alamat Blog dapat dibuka/ditemukan, tampilan Blog yang terdiri dari memasukkan tulisan/gambar, memasukkan musik dan tata letak Blog. Sedangkan, kemampuannya setelah diberikan soal tes berupa isian singkat mengenai materi Blog menunjukkan nilai 80 .
\end{abstract}

Kata kunci: kemampuan mahasiswa, penugasan, blog

\section{PENDAHULUAN}

Perkembangan teknologi yang terjadi saat ini tidak terlepas dari meningkatnya kebutuhan penggunaan teknologi dalam memperoleh informasi dan berkomunikasi. Saat ini informasi dan komunikasi dapat diperoleh dan dilakukan dimana saja dan kapan saja, dengan berbantuan teknologi tidak lagi dibatasi dimensi ruang dan waktu. Salah satunya teknologi internet setiap orang dapat mengakses berbagai macam informasi dan membagikan informasi tersebut melalui berbagai media, seperti media cetak, media sosial, maupun media lainnya tanpa dibatasi ruang dan waktu.

Begitu juga dalam dunia pendidikan, informasi tidak lagi hanya diperoleh di dalam kelas dimana pendidik memberikan informasi mengenai materi yang disampaikan dan peserta didik duduk manis mendengarkan. Kemajuan teknologi era ini sejatinya membantu pendidik dan juga peserta didik dalam memperoleh informasi yang dibutuhkan untuk pembelajaran di kelas. Bahkan pendidik juga dapat merancang pembelajaran menjadi lebih produktif, menyenangkan, mengasah kreatifitas peserta didik dengan melibatkan mereka secara langsung dalam pembelajaran.

Menurut Peraturan Pemerintah (PP) Standar Nasional Pendidikan Pendidikan Tinggi (SNP-PT) nomor 19 tahun 2005 mengenai Standar Proses pasal 19 menyatakan bahwa proses pembelajaran pada satuan pendidikan diselenggarakan secara interaktif, inspiratif, menyenangkan, menantang, memotivasi peserta didik untuk berpartisipasi aktif, serta memberikan ruang yang cukup bagi 
prakarsa, kreativitas, dan kemandirian sesuai dengan bakat, minat, dan perkembangan fisik serta psikologis peserta didik. Peraturan tersebut mengintruksikan kepada pendidik khususnya dosen agar menyelenggarakan proses pembelajaran di kelas yang mengajak peserta didik berpartisipasi aktif, merancang pembelajaran yang menantang peserta didik untuk berperan aktif dan menumbuhkan rasa ingin tahu sehingga mereka memiliki kreativitas dan kemandirian yang nantinya dapat dijadikan bekal bagi peserta didik saat berada di dunia kerja.

Karena itu, pendidik sebaiknya melibatkan TIK dalam proses pembelajaran di dalam kelas seperti LCD proyektor dan juga laptop. Selain itu, memanfaatkan internet untuk pembelajaran misalnya menugaskan mahasiswa mencari informasi mengenai materi yang akan dibahas menggunakan salah satu web untuk pembelajaran (blended learning) seperti edukasi.net, Edmodo, Quipper School; atau membuat blog dimana mereka memperoleh informasi yang kemudian menginformasikannya melalui blog. Hal tersebut dapat dijadikan sebagai salah satu cara menyikapi meningkatnya perkembangan teknologi saat ini. Apalagi bila dilihat dari penggunaan teknologi peserta didik, sebagian besar mereka memiliki handphone yang dilengkapi fasilitas internet dan juga laptop atau komputer PC. Artinya, peserta didik juga tidak tertinggal dalam mengikuti perkembangan teknologi yang terjadi era ini.

Namun berkembangnya teknologi informasi dan komunikasi saat ini dalam penggunaannya, peserta didik cenderung menggunakannya untuk media sosial seperti Facebook, Twitter, BBM, Instagram, Path dan lainnya. Sedangkan, penggunaan teknologi dalam memperoleh informasi dan mengkomunikasikannya secara spesifik untuk pembelajaran masih jarang digunakan. Berdasarkan hasil observasi yang peneliti lakukan pada peserta didik (mahasiswa) Pendidikan Geografi menunjukkan bahwa sekitar 76\% mahasiswa memiliki komputer PC atau laptop. Kemudian, sekitar $87 \%$ mahasiswa memiliki handphone yang juga memiliki fasilitas internet. Selanjutnya, dilihat dari penggunaan internet untuk membuat blog terdapat sekitar $25 \%$ mahasiswa pernah membuat Blog saat di sekolah maupun dengan keputusan sendiri membuat Blog. Sekitar $75 \%$ mahasiswa belum pernah membuat Blog dikarenakan mahasiswa tidak pernah ditugaskan membuat Blog sebelumnya. Saat di sekolah pun mahasiswa tidak banyak yang memiliki komputer yang terkoneksi dengan internet.

Blog merupakan situs web yang dapat dikelola oleh individu untuk menginformasikan berbagai macam informasi yang diinginkan pengguna Blog baik berupa politik, pendidikan, kesehatan, budaya, dan lainnya. Blog dapat digunakan secara gratis seperti penyedia layanan yang dimiliki Google yaitu Blogger. Selain itu, penyedia blog lain, seperti www.wordpress.com; www.Blogger.com; www.multiply.com dan banyak lagi lainnya yang dapat dikelola secara online dan gratis. TIK dalam pembelajaran seperti membuat Blog dapat dirancang dalam pembelajaran berbasis web di mana pendidik dapat melakukan pembelajaran dengan menjadikan blog sumber belajar bagi peserta didik dalam memperoleh informasi maupun bertukar informasi.

Blog adalah singkatan dari weblog. Blog adalah jenis situs web yang dikembangkan dan dikelola oleh individu dengan menggunakan perangkat lunak (software) online atau Platform host yang sangat mudah digunakan dengan ruang untuk menulis. Blog menampilkan publikasi online instan dan mengajak publik untuk membaca dan memberikan umpan balik sebagai komentar (Solomon dan Scrum,2011).

Selain itu, Blog dapat dikatakan sebagai buku harian online, pengguna dapat memasukkan catatan harian, peristiwa/ kejadian yang baru atau telah lama terjadi dan juga materi-materi seperti materi pelajaran bahkan informasi mengenai musik, sehingga pengguna dapat mengajak pembaca dan memberikan tanggapan mengenai informasi yang disampaikan oleh pengguna Blog. Pengguna Blog dapat menentukan domain yang digunakan untuk ditampilkan artinya pengguna Blog memiliki kebebasan dalam mengelola Blog baik bentuk, tampilan, pilihan warna maupun isi 
materi Blog. Adapun Blog yang digunakan dalam penelitian ini adalah www.blogger.com

Tuminto (2007) menyatakan bahwa kemampuan adalah kesanggupan, kecakapan atau kekuatan. Uno (2007) mengungkapkan bahwa hakikat kemampuan adalah dorongan internal dan eksternal pada siswa-siswa yang sedang belajar untuk mengadakan perubahan tingkah laku, pada umumnya dengan beberapa indikator atau unsur yang mendukung. Donald (Sardiman, 2009) mengemukakan kemampuan adalah perubahan energi dalam diri seseorang yang ditandai dengan munculnya pikiran dan didahului dengan tanggapan terhadap adanya tujuan. Kemudian, pengertian mahasiswa menurut Hartaji (2012) adalah seseorang yang sedang dalam proses menimba ilmu ataupun belajar dan terdaftar sedang menjalani pendidikan pada salah satu bentuk perguruan tinggi yang terdiri dari akademik, politeknik, sekolah tinggi, institut, dan universitas. Siswoyo (2007) mahasiswa dapat didefinisikan sebagai individu yang sedang menuntut ilmu ditingkat perguruan tinggi, baik negeri maupun swasta atau lembaga lain yang setingkat dengan perguruan tinggi. Jadi, berdasarkan beberapa pengertian tersebut dapat disimpulkan bahwa kemampuan mahasiswa adalah kesanggupan individu yang menjalani pendidikan tinggi dalam melakukan sesuatu untuk mengadakan perubahan tingkah laku dengan beberapa indikator atau unsur yang mendukung. Dalam hal ini kemampuan yang dimaksud adalah kecakapan, kesanggupan individu dalam mengerjakan tugas yang diberikan dosen pengampu berupa membuat Blog per individu secara mandiri.

Menurut Werkanis dan Hamadi (2005), metode penugasan atau resitasi memiliki tujuan sebagai berikut:

a. Membina rasa tanggung jawab yang dibebankan kepada siswa, melalui laporan tertulis atau lisan, membuat ringkasan, menyerahkan hasil kerja, dan lain-lain.

b. Menemukan sendiri informasi yang diperlukan.

c. Menjalin kerja sama dan sikap menghargai hasil kerja orang lain. d. Memperluas dan memperbanyak pengetahuan dan keterampilan.

e. Siswa terangsang untuk berbuat lebih baik.

f. Siswa terdorong untuk mengisi waktu.

g. Pengalaman siswa lebih terintegrasi dengan masalah yang berbeda dalam situasi baru.

h. Hasil belajar siswa lebih bermutu karena diikuti dengan bermacam model latihan.

Teknologi Informasi dan Komunikasi adalah teknologi yang digunakan untuk menangani informasi dan membantu cara komunikasi (pengolahan informasi) dengan bantuan perangkat lunak dan perangkat keras komputer untuk mengkonversikan atau mengubah, menyimpan, mengolah, mengirim dan menerima informasi (Fauziah dan Hedwig, 2010).

Menurut Kusnandar (2009) TIK dapat dimanfaatkan untuk mendukung proses pembelajaran yang dipercaya dapat;

a) Meningkatkan kualitas pembelajaran.

b) Memperluas akses terhadap pendidikan dan pembelajaran.

c) Mengurangi biaya pendidikan.

d) Menjawab keharusan berpartisipasi dalam ICT.

e) Mengembangkan keterampilan ICT (ICT skills) yang diperlukan siswa ketika bekerja dan dalam kehidupannya nanti.

Dalam kajian penelitian terdahulu (Sri Andayan, Kuswari Hernawati, dan Sahid: 2007) melakukan penelitian tindakan kelas yang bertujuan untuk meningkatkan kemampuan mahasiswa dalam penguasaan teknologi pembelajaran melalui tugas pembuatan media berbasis komputer dalam perkuliahan programmer

Hasil penelitiannya menunjukkan bahwa terjadi peningkatan kemampuan mahasiswa terhadap penguasaan teknologi pembelajaran yang di-tunjukkan dengan adanya media pembelajaran berbasis komputer yang telah disusun mahasiswa. Sebanyak 87\% mahasiswa mendapatkan nilai minimal batas tugas tersebut. Dukungan adanya peningkatan penguasaan teknologi pembelajaran juga diketahui dari $88 \%$ mahasiswa memberikan respon positif atas hal tersebut. 
Peningkatan kemampuan mahasiswa dalam penguasaan teknologi pembelajaran juga disertai dengan peningkatan hasil belajar dalam mata $\mathrm{k}$ uliah Pemrograman Kom-puter, yang ditunjukkan dengan 79\% mahasiswa mendapat nilai akhir minimal B-.

\section{METODOLOGI PENELITIAN}

Metode yang digunakan dalam penelitian ini adalah metode penelitian kualitatif. Sampel yang digunakan dalam penelitian ini adalah purposive sampling, yaitu kelas 3C berjumlah 33 mahasiswa. Pengambilan sampel ini dilakukan karena adanya tujuan tertentu, yakni mahasiswa di kelas tersebut belum pernah membuat Blog sebelumnya.

Teknik pengumpulan data pada penelitian ini , antara lain; 1) tes dilakukan bertujuan untuk mengetahui kemampuan kognitif mahasiswa mengenai materi Blog, soal yang diberikan berbentuk isian singkat sebanyak 10 soal; 2) dokumentasi yang digunakan berupa catatan, tugas, tabulasi, dan foto kegiatan pembelajaran di kelas. Analisis data dalam penelitian ini dilakukan secara kualitatif karena dalam penelitian ini cenderung deskriptif yakni menjabarkan/menggambar suatu kondisi berupa

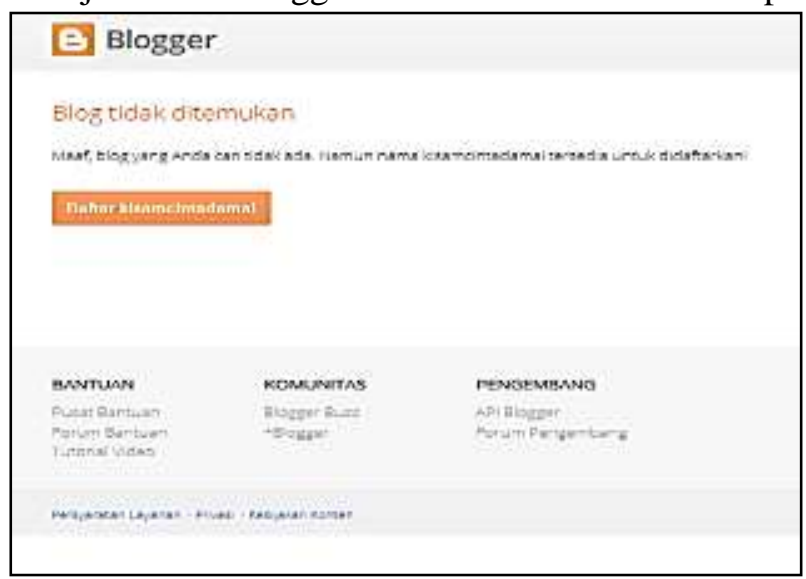

(a) mendeskripsikan kemampuan mahasiswa pendidikan geografi dalam membuat Blog.

\section{HASIL dan PEMBAHASAN}

Berdasarkan hasil tugas yang telah mahasiswa kumpulkan menunjukkan bahwa $97 \%$ mahasiswa mengumpulkan/memberikan alamat URL Blog yang telah dibuat, sisanya $3 \%$ tidak membuat tugas tersebut. Mahasiswa yang tidak mengumpulkan tugas mengatakan bahwa mahasiswa tidak memiliki komputer/laptop sehingga tidak dapat mengerjakan tugas. Kemudian, setelah diperiksa satu per satu alamat Blog yang telah dikumpulkan terdapat $83 \%$ dapat dibuka dan menampilkan Blog sesuai dengan alamat yang diberikan dan sisanya $17 \%$ alamat tersebut tidak bisa dibuka serta mengumpulkan alamat URL orang lain. Ini terlihat pada hasil tugas yang telah mahasiswa buat yaitu ketika dibuka alamat URL tersebut bukan Blog milik mahasiswa melainkan Blog orang lain. Salah satu tugas mahasiswa tersebut dapat dilihat pada gambar 1a dan gambar $1 b$.

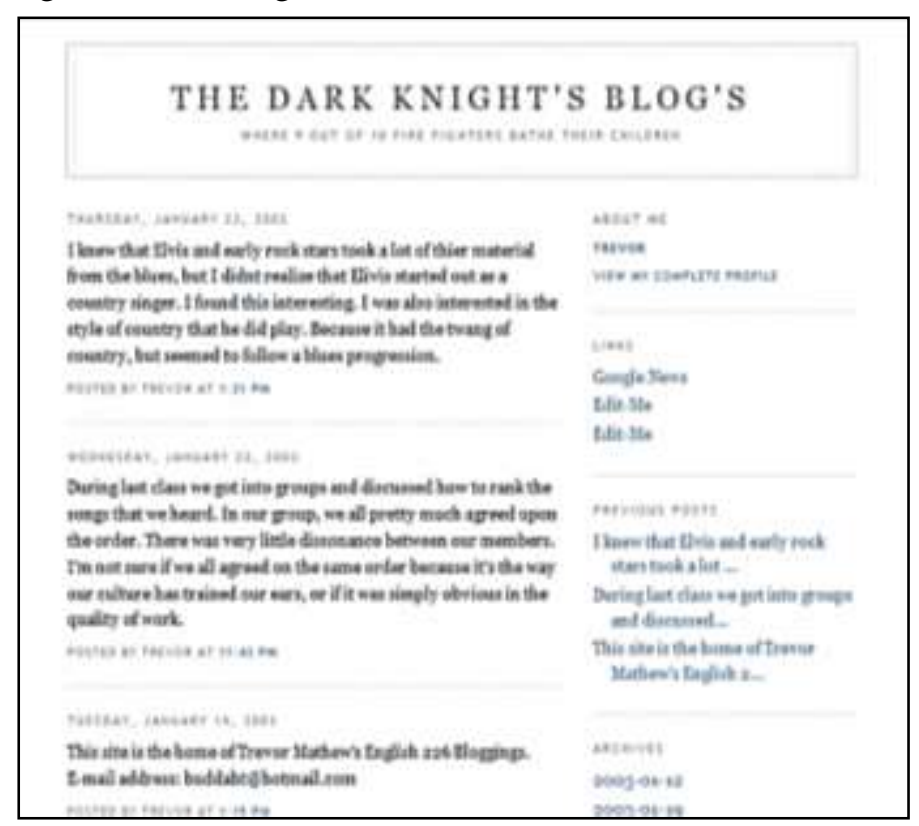

(b)

Gambar 1. (a) Alamat Blog yang tidak dapat ditampilkan/ditemukan; (b) Alamat blog milik orang lain

Kemudian, bila dilihat dari tampilannya yang terdiri dari menampilkan tulisan maupun gambar, musik, dan tata letak, yakni terdapat $80 \%$ mahasiswa dapat memasukkan/menampilkan tulisan atau gambar, selebihnya tidak memasukkan tulisan tetapi hanya terdapat judul Blog; $75 \%$ mahasiswa dapat memasukkan musik ke dalam Blog dan selebihnya tidak memasukkan musik ke 
dalam Blog. Selanjutnya, terdapat $80 \%$ mahasiswa dapat menampilkan tata letak dengan baik dimana mahasiswa menampilkan Blog dengan rapi diantaranya adanya judul Blog, profil pemilik Blog, pemberitahuan/arsip tulisan yang di-entrikan yang tersusun di samping kanan atau kiri muka Blog. Tugas Blog mahasiswa yang menampilkan Blog yang kurang baik dan tampilan blog mahasiswa dengan memasukkan tulisan/gambar, musik, dan tata letak yang baik dapat dilihat pada gambar 2a dan gambar $2 b$.

(a)

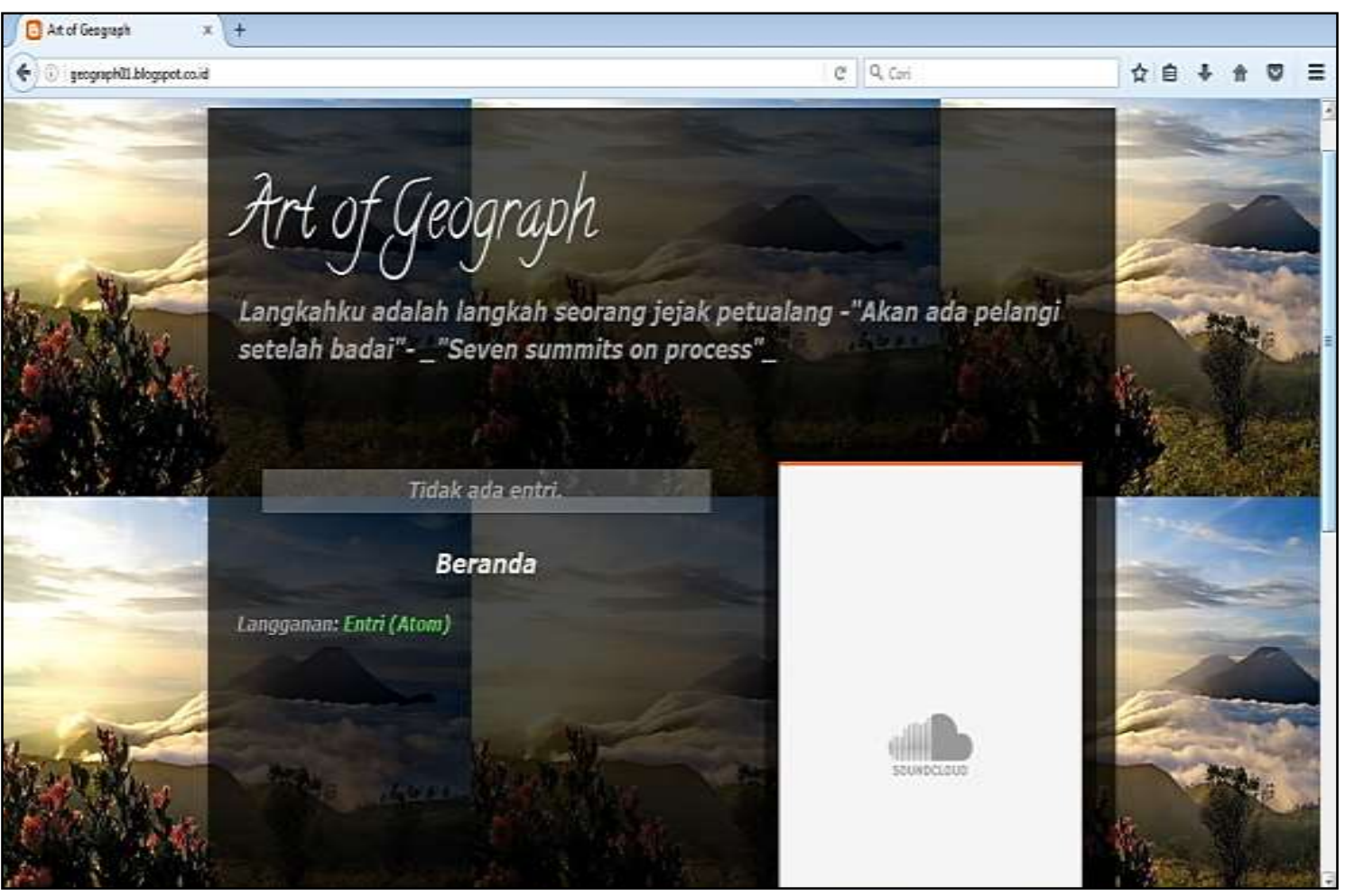

(b)

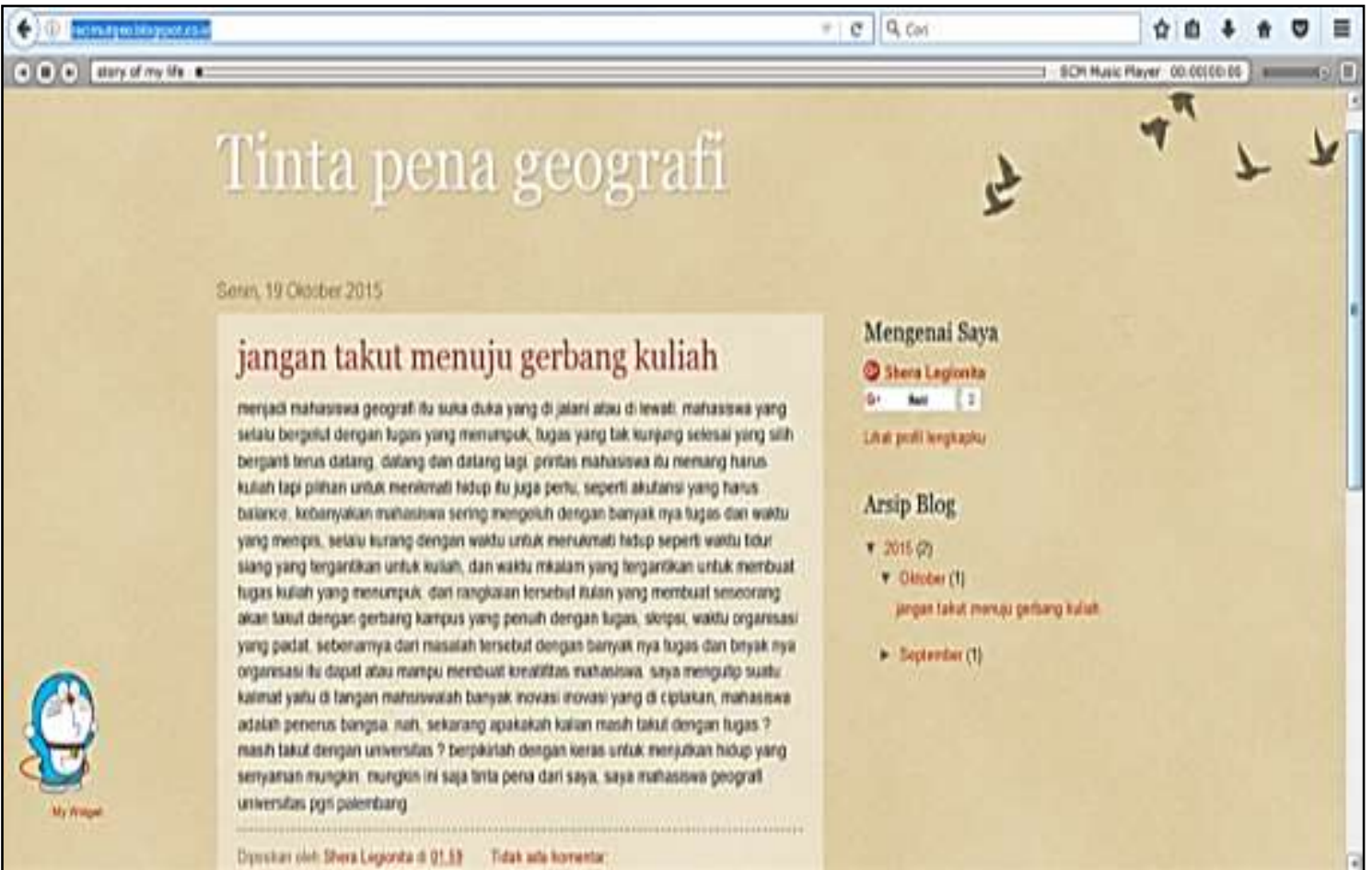

Gambar 2. (a) Mahasiswa tidak memasukkan tulisan dan tata letak yang kurang baik; (b) Mahasiswa menampilkan tulisan, musik, dan tata letak dengan baik 
Selain kemampuan mahasiswa Pendidikan Geografi dilihat dari kemampuanya dalam membuat Blog, setelah dilakukan tes mengenai materi Blog secara keselurahan rata-rata hasil tes kelas 3C menunjukkan nilai 80 (delapan puluh). Secara keseluruhan kemampuan mahasiswa Pendidikan Geografi dalam membuat Blog dapat dilihat pada gambar 3.

Berdasarkan uraian tersebut, maka dapat disimpulkan bahwa kemampuan mahasiswa dalam membuat Blog secara keseluruhan setelah dirataratakan terdapat $83 \%$ dengan kategori Baik. Artinya, mahasiswa dapat membuat Blog dengan baik yakni dilihat dari mengumpulkan alamat URL Blog, Alamat Blog dapat dibuka, tampilan Blog yang terdiri dari memasukkan tulisan/gambar, memasukkan musik dan tata letak Blog. Sedangkan, kemampuannya setelah diberikan soal tes isian mengenai materi Blog menunjukkan nilai 80 .

Agar dapat membuat Blog diperlukan jaringan internet dan perangkat lainnya berupa komputer PC ataupun Laptop serta perangkat lunak berupa Mozila atau Google Crome. Selain itu, adanya langkah-langkah yang harus diselesaikan sehingga Blog dapat tampilkan, yaitu dimulai dari membuat akun, menentukan alamat Blog, men-setting tampilan, memasukkan tulisan/gambar dan musik.

Sebelum memberikan tugas kepada mahasiswa untuk membuat Blog secara mandiri, dosen memberikan penjelasan kepada mahasiswa mengenai langkah-langkah membuat Blog agar mahasiswa dapat melaksanakan tugas membuat blog dengan baik. Kemampuan mahasiswa dalam membuat Blog dapat diukur bila mahasiswa mengumpulkan tugas itu dengan memberikan alamat Blog, kemudian melakukan pemeriksaan tugas dengan mengecek alamat Blog yang diberikan dapat ditemukan/ dibuka, memasukkan tulisan/gambar, memasukkan musik serta tampilan tata letak Blog.

Berdasarkan hal tersebut bila dilihat dari pengertianya yaitu kemampuan mahasiswa merupakan kesanggupan individu yang menjalani pendidikan tinggi dalam melakukan sesuatu untuk mengadakan perubahan tingkah laku dengan

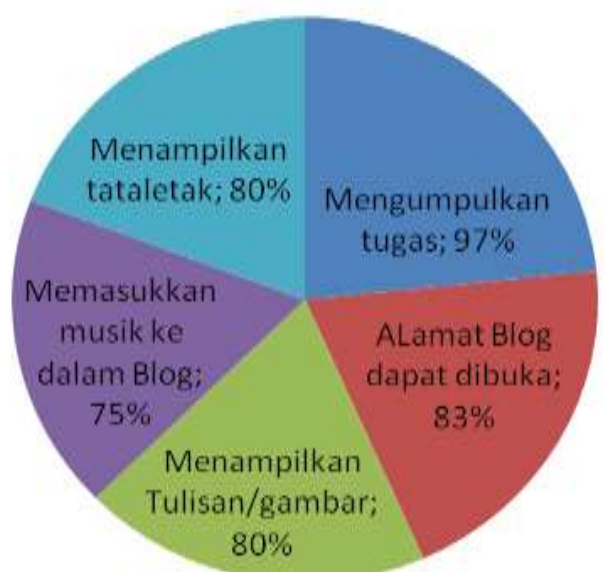

Gambar 3. Diagram kemampuan mahasiswa Pendidikan Geografi dalam penugasan pembuatan blog

beberapa indikator atau unsur yang mendukung. Maka, dilihat dari hasil penelitian menunjukkan bahwa 97\% mahasiswa mengumpulkan/memberikan alamat URL Blog yang telah dibuat. Setelah diperiksa satu per satu alamat Blog yang telah dikumpulkan terdapat $83 \%$ dapat dibuka/ ditermukan dan menampilkan Blog sesuai dengan alamat yang diberikan.

Kemudian, terdapat $80 \%$ mahasiswa dapat memasukkan/menampilkan tulisan; $75 \%$ mahasiswa memasukkan musik ke dalam Blog; $80 \%$ mahasiswa menampilkan tata letak dengan baik dimana mahasiswa menampilkan Blog dengan rapi diantaranya adanya judul Blog, profil pemilik Blog, pemberitahuan/arsip tulisan. Jadi, secara keseluruhan setelah dirata-ratakan terdapat $83 \%$ dan termasuk kategori baik. Artinya, mahasiswa dapat membuat Blog dengan baik yakni dilihat dari kemampuannya membuat Blog dan mengumpulkan alamat URL Blog, Alamat Blog dapat dibuka/ditemukan, tampilan Blog yang terdiri dari memasukkan tulisan/gambar, memasukkan musik dan tata letak Blog. Sedangkan, kemampuannya setelah diberikan soal tes isian mengenai materi Blog menunjukkan nilai 80 .

Adapun, hal-hal yang perlu diperhatikan dalam membuat Blog adalah tersedianya akses Internet yang cukup tinggi agar proses pembuatan Blog tidak terhambat, kemudian untuk penulisan alamat Blog sebaiknya menggunakan kata-kata yang familiar dan lebih enak di dengar sebab 
terdapat beberapa mahasiswa yang membuat Blog dengan menggunakan alamat Blog berupa bellaputus.blogspot.com, kadekputus.blogspot.com.

\section{SIMPULAN}

Secara keseluruhan kemampuan mahasiswa pendidkan Geografi terdapat $83 \%$ dan termasuk kategori baik. Artinya, mahasiswa dapat membuat Blog dengan baik yakni dilihat dari kemampuannya membuat Blog dan mengumpulkan alamat URL Blog, alamat Blog dapat dibuka/ditemukan, tampilan Blog yang terdiri dari memasukkan tulisan/gambar, memasukkan musik dan tataletak Blog. Sedangkan, kemampuannya setelah diberikan soal tes isian mengenai materi Blog menunjukkan nilai 80 .

\section{DAFTAR PUSTAKA}

Anonim. 2005. Standar Proses. Peraturan Pemerintah (PP) Standar Nasional Pendidikan Pendidikan Tinggi (SNP-PT) Nomor 19 Tahun 2005.
Hartaji, Damar A. (2012). Motivasi Berprestasi Pada Mahasiswa yang Berkuliah Dengan Jurusan Pilihan Orangtua. Fakultas Psikologi Universitas Gunadarma. (tidak diterbitkan)

Fauziah dan Rinda Hedwig. 2010. Pengantar Teknologi Informasi. Bandung: CV. Muara Indah.

Kunandar. 2009. Guru Profesional: Implementasi KTSP dan Sukses dalam Sertifikasi Guru. Jakarta: Rajawali Press

Siswoyo, Dwi dkk. 2007. Ilmu Pendidikan. Yogyakarta: UNY Press

Sardiman, A.M. 2009. Interaksi \& Motivasi Belajar Mengajar. Jakarta: PT RajaGrafindo Persada

Solomon, Gween dan Lynne Scrum.2011. Web 2.0 Panduan bagi para pendidik Jakarta : PT indekx

Suryana,Oya dan Mataya Studio.2008. Membanggun Blog Wordpress. Jakarta: PT elex Media Komputindo.

Roestiyah N.K. Tanpa Tahun. Strategi Belajar Mengajar. Jakarta: Rineka Cipta.

Tuminto, Didik. 2007. Keterampilan Berbahasa. Jakarta: Rajawali Pres

Werkanis AS dan Marlius Hamadi. 2005. Strategi Mengajar. Pekanbaru: PT Sutra Benta Perkasa 


\section{Jurnal SWARNABHUMI}

Jurnal Geografi dan Pembelajaran Geografi

\section{Diterbitkan oleh:}

Program Studi Pendidikan Geografi

Fakultas Keguruan dan Ilmu Pendidikan

Universitas PGRI Palembang

Jurnal Swarnabhumi merupakan jurnal yang diterbitkan oleh Program Studi Pendidikan Geografi, Universitas PGRI Palembang pada tahun 2016 yang masih memiliki versi cetak. Jurnal ini mempublikasikan artikel di bidang ke-geografi-an dan pembelajaran Geografi. 